dr hab. Jerzy ZEMKE, prof. UG

Wydział Zarządzania, Uniwersytet Gdański

e-mail: jerzy.zemke@ug.edu.pl

DOI: $10.15290 /$ ose.2017.03.87.04

\title{
METODA MONTE CARLO W OCENIE RYZYKA FINANSOWEGO INWESTYCJI
}

\begin{abstract}
Streszczenie
Zmiany uwarunkowań otoczenia decyzji inwestycyjnych mogą znacząco różnić się od przyjętych w planach i to różnice między założonymi uwarunkowaniami a ich rzeczywistymi wartościami są źródłem ryzyka finansowego inwestycji. Ocenę ryzyka najpełniej rozwinął sektor finansów. Nie oznacza to, że problem został w pełni zbadany i nie ma już miejsca na nowe rozwiązania. Celem badania jest konstrukcja instrumentu pomiaru ryzyka finansowego inwestycji wykorzystującego generator Monte Carlo. Przyjęto miarę efektywności inwestycji - stopę zwrotu brutto, a jakość instrumentu pomiaru ryzyka zweryfikowano empirycznie, szacując ryzyko stopy zwrotu zakupu pakietu akcji banku przez Zakład Ubezpieczeń. Wynik użycia Metody Monte Carlo potwierdza tezę o wzroście ryzyka wraz ze wzrostem oczekiwanej stopy zwrotu z inwestycji.
\end{abstract}

Słowa kluczowe: ryzyko finansowe inwestycji, instrumenty pomiaru ryzyka, metoda Monte Carlo

\section{MONTE CARLO METHOD IN ESTIMATING FINANCIAL RISK OF INVESTMENTS}

\section{Summary}

The problem of risk has been explored most exhaustively by the financial sector. This does not mean, however, that the subject is closed to discussion. Forecasting the possible states of process risk is the most crucial element of decision-making - not only in the field of finance. Most forecasts are characterised by low reliability - most frequently, they do not prove true. The study proposes a design of a flexible instrument for measuring the financial risk of investment decisions, using the Monte Carlo generator. The instrument is intended to enable the adjustment of decision-making processes so as to keep the process risk within acceptable limits.

Key words: financial risk of investments, instruments of risk measuring, Monte Carlo method

JEL: C15, G11 


\section{Wstęp}

Teoria i praktyka finansowania inwestycji szczególnym zainteresowaniem darzy koncepcję równowagi pomiędzy miara generowanych korzyści - zysku a niepewnością wypracowywania tej formy premii. Niepewność jest bliżej nieokreślona i często trudno ten stan wyskalować. Ze wspomnianą niepewnością łączy się inne pojęcie. Jest nim ryzyko, przez które rozumie się stan realizacji procesów decyzyjnych w warunkach zmienności uwarunkowań otoczenia decyzyjnego ${ }^{1}$.

Celem opracowania jest ukazanie możliwości użycia metody Monte Carlo do oceny ryzyka finansowego inwestycji. O ile skutki funkcjonowania w warunkach niepewności są trudne do określenia z uwagi na brak bądź mało precyzyjne skalowania tego stanu, to już identyfikowalne skutki ryzyka pozwalają na jego pomiar. W tym kontekście uznanie miary ryzyka za miarę niepewności przyszłych korzyści jest w pełni uzasadnione.

Zmienność uwarunkowań otoczenia decyzyjnego skłania do uwzględniania różnych wariantów scenariuszy procesów inwestycyjnych i w następstwie pomiaru efektywności każdego z nich. Istotą metody Monte Carlo jest możliwość wygenerowania dowolnej, skończonej liczby wyników inwestycji kapitałowej. Otwiera to szanse pomiaru ryzyka, a w konsekwencji ocenę stanu niepewności przyszłych korzyści inwestora. Pomiar ryzyka przy użyciu metody Monte Carlo jest szacunkiem przybliżonym, ale i takiej jakości informacja może być podstawą korekt procesu inwestycyjnego w warunkach ryzyka.

\section{Finansowania inwestycji, niepewność, ryzyko}

Finansowanie inwestycji wymaga odpowiedzi na fundamentalne pytanie o źródła kapitału finansującego projekty. Czy kapitałem dominującym będzie kredyt bankowy, kapitał pochodzący z emisji akcji, kapitał pochodzący z emisji, obligacje, kapitał pomocowy czy kapitał uzupełniający, czyli: kapitał własny, krótkoterminowe kredyty bankowe i pożyczki, emisja krótkoterminowych papierów dłużnych, leasing, zobowiązania krótkoterminowe? Wybór rodzaju kapitału finansującego inwestycje zależy od: jego dostępności, stabilności, terminowości, dopływu w czasie jej realizacji, kosztu pozyskania, a także reakcji właścicieli na możliwy spadek wartości ich aktywów [Hay, Morris, 1987; Rappaport, 1986; Coates i in. 1993]. Rodzaj kapitału inwestycyjnego wpływa na efektywność inwestycji, bowiem należy uwzględnić koszty pozyskania kapitału.

Realizacja inwestycji jest monitorowana w kontekście zgodności przyjętych w planach uwarunkowań otoczenia inwestycyjnego $z$ ich aktualnym stanem. W przypadku istotnych różnic narasta niepewność uzyskania planowanej stopy zwrotu². Oznacza to

1 Obszarem uwarunkowań bezpośrednich organizacji są: zasoby, kompetencje, strategie, mikrootoczenie, otoczenie konkurencyjne i makrootoczenie [Gołębiowski, 2001, s. 103-119].

2 Interesujący wynik uzyskał Mark K. Kritzman, a mianowicie dowiódł on, że wartość oczekiwana zokreślonej próby stóp zwrotu na ogół przewyższa zrealizowanq wartość tej próby, podczas gdy bardziej prawdopodobne jest, że

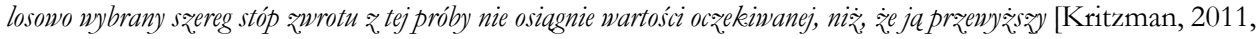
s. 59]. 
konieczność prowadzenia kontroli dynamiki i kierunku zmian uwarunkowań otoczenia inwestycyjnego, a w konsekwencji wyboru właściwego scenariusza realizacji inwestycji.

Z niepewnością uzyskania zwrotu łączy się ryzyko towarzyszące realizowanym procesom inwestycyjnym ${ }^{3}$. Postrzegając ryzyko jako skutek wpływu turbulencji uwarunkowań otoczenia inwestycyjnego na wynik podjętych działań, nie popełnia się błędu uznając miarę ryzyka za miarę stanu niepewności realizowanego procesu inwestycyjnego. Pomiar ryzyka inwestycyjnego redukuje niepewność inwestora spowodowaną wpływem zmian otoczenia na realizowany cel inwestycji.

\section{1. Źródła niepewności}

Procesy inwestycyjne są realizowane w otoczeniu uwarunkowań identyfikowanych jako zasoby własne, takie jak: wiedza, kompetencje, kultura organizacyjna, potencjał pracowniczy, struktura organizacyjna, majątek materialny i niematerialny, kapitały. Zasób własny dopełniają czynniki bliskiego otoczenia rynkowego, tj.: potencjał konkurentów rynkowych, uwarunkowania środowiska naturalnego, zasoby rynku pracy, relacje z dostawcami, cechy środowiska kulturowego, ale także makrootoczenia obejmującego uwarunkowania: polityczne, ekonomiczne, prawne, finansowe, kulturowe [Thomson, Strickland, 1998].

Otoczenie inwestycyjne jest źródłem niepewności. Zarządzanie w warunkach zmian uwarunkowań otoczenia uświadamia konieczność uwzględnienia różnych wariantów inwestycyjnych, nawet jeśli tylko niewielka liczba uwarunkowań otoczenia decyzyjnego ulega zmianom, które istotnie różnią się od inwestycji przyjętych w założeniach.

\subsection{Metody analizy ryzyka}

Ryzyko inwestycji jest skutkiem zmienności otoczenia decyzyjnego, a fundamentem analizy ryzyka jest monitoring zmian jego uwarunkowań. Wynik analizy umożliwia identyfikację decyzji mających korzystny wpływ na cel inwestycyjny. Można na to spojrzeć także z innej perspektywy. Wyniki monitoringu mogą mieć walor ostrzegawczy, bowiem informują o zagrożeniach realizacji celu inwestycyjnego.

Monitoring zmian uwarunkowań otoczenia decyzyjnego pozwala na ocenę trendu oraz dynamiki uwarunkowań istotnych dla realizowanych celów inwestycyjnych. Ocena ta ma miejsce za sprawa:

1. analizy wrażliwości celów inwestycyjnych na zmiany uwarunkowań; jej wynik służy określeniu wartości krytycznych uwarunkowań otoczenia decyzyjnego, dzięki którym jest możliwa realizacja planowanych celów;

\footnotetext{
${ }^{3}$ Pojęcia niepewności i ryzyka często są postrzegane jako pojęcia tożsame. Jest to nieuprawnione, bowiem niepewność to niezmierzony stan ,niepokoju” o rezultat podjętych działań, natomiast ryzyko jest kategoria mierzalną i określa liczbowo jego poziom.
} 
2. metod statystycznych do wyznaczania trendów zmian uwarunkowań w horyzoncie realizacji inwestycji;

3. symulacji realizacji celów inwestycji według zróżnicowanych scenariuszy, a w okresie zwrotu nakładów prowadzenia symulacji procesów decyzyjnych zapewniających planowany poziom efektywności inwestycji.

Analiza wrażliwości celów inwestycyjnych na zmiany uwarunkowań realizowanego procesu przy użyciu metod prognozowania uwarunkowań ma umożliwić pogłębienie analizy podjętego ryzyka. Dotyczy to ważnej odpowiedź na pytanie o granice dopuszczalnych zmian uwarunkowań otoczenia decyzyjnego stabilizujących poziom ryzyka. Analizę tę uzupełnia symulacja wyników realizacji projektów inwestycyjnych w warunkach różnych wariantów scenariuszy działań. Wynik symulacji ma odpowiedzieć na pytanie, które ze scenariuszy chronią najskuteczniej cel inwestycyjny przed skutkami podjętego ryzyka. Jest to równoważne z redukcją stanu niepewności wyniku, a tym samym wyborem scenariusza procesu decyzyjnego.

\subsection{Pomiar ryzyka inwestycyjnego}

Inwestycja to rezultat nabycia lub wytworzenia składników aktywów: rzeczowych majątku trwałego, wartości niematerialnych i prawnych, a w ujęciu praw majątkowych: licencji, znaków towarowych, patentów. Celem każdej inwestycji jest jej opłacalność. Inwestor alokuje kapitał, ponosząc nakłady inwestycyjne, liczy na przyszłe dochody.

Realizacja inwestycji jest procesem warunkowym, który zachodzi w dynamicznie zmieniającym się otoczeniu decyzyjnym, a zmiany otoczenia sa przyczyną niepewności co do rezultatów realizowanego procesu inwestycyjnego. Możliwość pomiaru niepewności na każdym etapie realizacji jest istotnym warunkiem ograniczającym niekorzystne skutki wystąpienia różnic między uwarunkowaniami planu inwestycyjnego a uwarunkowaniami otoczenia w toku realizacji inwestycji. Pomiar niepewności pośrednio jest realizowany dzięki pomiarowi ryzyka inwestycyjnego. Literatura problemu jest zasobna i tym samym wyróżnia pomiar ryzyka mający wartość sprawozdawczą expost oraz pomiar o wartości ostrzegawczej ex ante. Pomiar ex ante ma istotne znaczenie w procesach zarządzania w warunkach ryzyka. Pomiar ryzyka na podstawie bieżących informacji o zmianach uwarunkowań otoczenia decyzyjnego umożliwia dobór skutecznych instrumentów chroniących realizowane procesy inwestycyjne przed niekorzystnym wpływem zmian uwarunkowań.

Pomiary ryzyka inwestycyjnego, dokonywane metodami statycznymi bądź dynamicznymi, maja zróżnicowaną wartość informacyjną. Różni je rola czasu w procedurze pomiaru efektywności inwestycji. W przeciwieństwie do metod dynamicznych, metody statystyczne nie zakładają zmienności wartości pieniądza w czasie ${ }^{4}$. Nie oznacza

\footnotetext{
4 Metody statyczne to: rachunek porównawczy kosztów, rachunek porównawczy zysków, rachunek rentowności, okres zwrotu [Ostrowska, 1999; Rogowski, 2008], natomiast metody dynamiczne to: metoda wartości bieżącej NPV i metoda wewnętrznej stopy zwrotu IRR [Jajuga, 2009].
} 
to, że wyniki uzyskane metodami statystycznymi są bezwartościowe, odwrotnie, mają znaczenie informacyjne i stanowią wstępną, przybliżoną ocenę ryzyka finansowego inwestycji.

Wyniki monitoringu dynamiki zmian uwarunkowań otoczenia decyzyjnego stanowia podstawę procesów prognozowania stanów otoczenia decyzyjnego. Naturalnym wykorzystaniem prognoz jest ich użycie do szacowania ryzyka możliwych scenariuszy zarządzania procesem inwestycyjnym.

Problem pomiaru ryzyka nabiera szczególnego znaczenia wówczas, gdy uwarunkowania są wielkościami jakościowymi - niematerialnymi. W powszechnej ocenie, zmienne mające wymiar jakościowy są niemierzalne [Hubbard, 2014]. Jeżeli jednak ważne decyzje wymagają uwzględnienia uwarunkowań przyjmujących wartości jakościowe, a w przypadku oceny ryzyka inwestycyjnego tak jest i decydent postrzega je jako niemierzalne, to $z$ dużym prawdopodobieństwem można uznać, że nie zostaną podjęte nawet próby ich pomiaru. W rezultacie część uwarunkowań, mających wpływ na poziom ryzyka, nie jest uwzględniana w jego pomiarze, tymczasem problem skutków pominięcia nawarstwia się w kolejnych fazach monitoringu zmian efektywności realizowanej inwestycji.

\subsection{Metoda Monte Carlo}

Stochastyczna natura zjawisk oznacza, że jednoznaczne wskazanie wyniku pomiaru zjawiska jest niemożliwe. Jeżeli założy się rozkład prawdopodobieństwa stanów badanego zjawiska, to już samo określenie przedziału miary stanów jest zadowalającym wynikiem. Koncepcja takiego rozwiązania sięga XVIII wieku. Louis Leclerc hrabia Buffon, analizując problem wnioskowania w warunkach ograniczonej wiedzy o zachodzących zjawiskach, stwierdził, że jeśli przyczyny zjawisk są jasne i zrozumiałe, to sformułowaniu wniosków może posłużyć analogia lub powtarzalność zjawisk [Leclerc, 2010, s. 18 i następ.].

Koncepcja rozwiazania pomiaru, według idei Leclerca, w obecnej formie została opublikowana w 1949 roku przez Metropolisa i Ulama, a rozwiązanie jest znane pod nazwą symulacji Monte Carlo5. Literatura problemu zna różne definicje metody: [Halton, 1970, s. 2; Metropolis, Ulam, 1949, s. 335; Jäckel, 2002; Sobol, 1975]. W wymienionych pozycjach zdefiniowano założenia metody symulacyjnej. Na potrzeby tego opracowania wybrano sformułowanie Haltona. Jest ono zrozumiałe, jak również opiera się na znajomości podstaw statystyki oraz analizy matematycznej. Zacytowano je poniżej.

Definicja. Metoda Monte Carlo jest to metoda reprezentujaca rozwiazanie problemu w postaci parametru pewnej hipotetycznej populaci i usywajaca sekwencji liczb losowych do skonstruowania próby losowej danej populacij, z której to statystyczne oszacowania tego parametru moga być otraymane.

\footnotetext{
${ }^{5}$ Zob. [Metropolis, 1987]. Instrumenty narzędziowe użyte w metodzie mają swoje źródło w analizie gier losowych. Metropolis potwierdził, że Ulam zainspirował go opowiadaniami o swoim wuju, namiętnym hazardziście, bywalcu kasyn w Monte Carlo. Stanisław Ulam urodził się w Polsce w rodzinie żydowskiej, matematyk, przedstawiciel szkoły lwowskiej, współtwórca bomby termojądrowej (obywatelstwo amerykańskie przyjąl dopiero w 1943 roku).
} 
Do wygenerowania hipotetycznej populacji jest wykorzystywany generator liczb losowych (ang. random number generator - RNG), a wynikiem działania generatora liczb losowych są liczby z przedziału o rozkładzie jednostajnym. Z generatora o takim rozkładzie można uzyskać generator o dowolnym, innym rozkładzie przez wyznaczenie funkcji odwrotnej do dystrybuanty otrzymanej na podstawie wyników pierwszego generatora [Zieliński, 1979].

\subsubsection{Metoda odwracania dystrybuanty}

Założenia:

1. $\mathrm{R}$ - zmienna losowa o rozkładzie równomiernym w przedziale $(0,1)$;

2. $\mathrm{F}$ - pewna ciąła i ściśle rosnąca funkcja, taka, że $\mathrm{F}(-\infty)=0, \mathrm{~F}(+\infty)=1$.

Niech zmienna losowa $\mathrm{X}$ jest funkcją odwrotną dystrybuanty rozkładu zmiennej losowej $\mathrm{R}$, to $\mathrm{X}=\mathrm{F}^{-1}(\mathrm{R})$.

Zatem $z$ relacji $\mathrm{P}\{\mathrm{X} \leq \mathrm{x}\}=\mathrm{P}\left\{\mathrm{F}^{-1}(\mathrm{R}) \leq \mathrm{x}\right\}$ i $\mathrm{P}\left\{\mathrm{F}^{-1}(\mathrm{R}) \leq \mathrm{x}\right\}=\mathrm{P}\{\mathrm{R} \leq \mathrm{F}(\mathrm{x})\}=\mathrm{F}(\mathrm{x})$ wynika, że zmienna losowa $\mathrm{X}$ ma rozkład o dystrybuancie $\mathrm{F}$.

Niech $\left\{\mathrm{r}_{\mathrm{n}}\right\}, \mathrm{n}=1,2, \ldots$ jest ciagiem liczb losowych o rozkładzie równomiernym w przedziale $(0,1)$, to ciag $\left\{x_{n}\right\}, n=1,2, \ldots$, gdzie $x_{n}=F^{-1}\left(r_{n}\right)$ jest ciagiem liczb losowych o dystrybuancie F.

Praktyczne rozwiązanie zadania generowania ciagu liczb losowych $\left\{\mathrm{x}_{\mathrm{n}}\right\}$ podał Kahn [Tocher, 1969; Zieliński, 1970], proponując rozwiązanie przybliżone, mianowicie aproksymantę funkcji odwrotnej $\mathrm{F}^{-1}$ :

$$
\exp \left(-\frac{1}{2} x^{2}\right) \approx \frac{4 e^{-k x}}{\left(1+e^{-k x}\right)^{2}} ; k=\sqrt{\frac{8}{\pi}}, \quad x \geq 0,
$$

stąd:

$$
x=\frac{1}{k} \ln \frac{1+R}{1-R}, 0<R<1 \text {. }
$$

Jeżeli $\mathrm{R}$ ma rozkład równomierny w przedziale $(0,1)$, to $\mathrm{X}$ ma w przybliżeniu taki rozkład jak wartość bezwzględna zmiennej losowej o rozkładzie normalnym $(0,1)$.

Załóżmy, że zmienna losowa X ma rozkład normalny $\mathrm{N}(0,1)$ o rozkładzie gęstości:

$$
\varphi(x)=\frac{1}{\sqrt{2 \pi}} \exp \left(-\frac{x^{2}}{2}\right),-\infty<x<+\infty .
$$

Wygenerowanie zmiennej Z o rozkładzie normalnym $\mathrm{N}(\mu, \sigma)$ poprzedza wygenerowanie zmiennej $\mathrm{X}$ zgodnie $\mathrm{z}$ rozkładem (3), a następnie wyznaczenie zmiennej $Z=\sigma X+\mu$.

Metoda odwracania dystrybuanty w przypadku funkcji $y=\varphi(x)$ obejmuje następujące założenia: 
1. $\exp \left(-\frac{1}{2} x^{2}\right) \approx \frac{4 e^{-k x}}{\left(1+e^{-k x}\right)^{2}} ; k=\sqrt{\frac{8}{\pi}}, \quad x>0$,

2. ograniczenie aproksymacji funkcji (3) do dodatniej półosi jest równoznaczne $\mathrm{z}$ aproksymacją dystrybuanty rozkładu normalnego o parametrach $\mathrm{N}(0,1)$ uciętego do wartości dodatnich:

$$
y=\varphi(x), \Rightarrow y=\frac{2}{1+e^{-k x}}-1,
$$

3. $\mathrm{z}$ relacji (5) wyznaczamy funkcję $x=\frac{1}{k} \ln \frac{1+y}{1-y}, \quad 0<y<1$, która jest przybliżeniem funkcji odwrotnej.

Jeżeli zmienna losowa $y$ ma rozkład równomierny w przedziale $(0,1)$, to zmienna losowa $x$ ma w przybliżeniu rozkład normalny ucięty do wartości dodatnich, tzn. rozkład o gęstości:

$$
p(x)=\sqrt{\frac{2}{\pi}} \exp \left(\frac{x^{-2}}{2}\right), \quad x>0^{6} .
$$

Funkcja rozkładu gęstości zmiennej losowej jest potencjalnym instrumentem redukcji niepewności wynikającej ze stochastycznej natury zjawisk ekonomicznych, bowiem umożliwia przeprowadzenie procesu generowania ciagu wartości losowych stóp zwrotu z inwestycji. Wprawdzie idea procedury pomiaru daje jedynie pewne przybliżenie miary, to już sam fakt możliwości określenia jej przedziału sprawia, że wzrasta zasób informacji, które stanowią fundament procesu podejmowania decyzji inwestycyjnych.

\section{Ryzyko finansowania inwestycji}

Przywilejem inwestora jest decyzja inwestycyjna, ale jednocześnie to inwestor ponosi skutki podjętej decyzji. Analiza bieżących uwarunkowań decyzji obejmuje także, co oczywiste, pomiar stopy zwrotu z inwestycji w aktualnych uwarunkowaniach.

Stopa zwrotu inwestycji jest definiowana jako relacja średniego rocznego zysku w okresie zwrotu nakładów do skali finansowania inwestycjī.

Analiza ryzyka finansowania inwestycji koncentruje się na monitoringu zmian wartości stopy zwrotu, a w przypadku trendu spadkowego na wskazaniu przyczyn tego

\footnotetext{
${ }^{6}$ Uzasadnienie zamieścił Zieliński w rozdziale pt.: Generatory licz̧b losowych o dowolnych rozkładach prawdopodobieństwa [Zieliński, 1979].

7 Obok miary efektywności inwestycji, jaką przyjęto w tym opracowaniu, literatura zagadnienia wymienia: koszt/zysk w jednostce czasu - na etapie wyboru wariantu inwestycyjnego, okres zwrotu, rentowność [Karpuś, 2003]. Celem uproszczenia badania przyjęto zysk brutto.
} 
niekorzystnego stanu. Definicja ryzyka powinna uwzględniać przyjęte założenia analizy finansowej, tak by w konsekwencji formalny opis ryzyka otwierał możliwość budowy modelu ryzyka, a następnie pomiar ryzyka. Definicję tę przedstawiono poniżej.

Ryzyko finansowe inwestycii jest zdarzeniem zrealizowania stopy zurotu zinwestycï na poziomie niższym aniżli stopa zurotu zaktadana w planach inwestora.

Modelem odzwierciedlającym przekaz definicji ryzyka jest obraz rozstępu $m_{r}$ między zrealizowaną stopą zwrotu a jej wartością planowaną, zatem:

gdzie:

$$
m_{r}=\left\{\begin{array}{l}
s-s^{(p)} \geq 0, \quad(A) \\
s-s^{(p)}<0, \quad(B)
\end{array},\right.
$$

$s-$ zrealizowana stopa zwrotu inwestycji,

$s^{(P)}$ - planowana stopa zwrotu,

(A) - A zdarzenie: zwrot z inwestycji na poziomie planowanym,

(B) $-B$ zdarzenie: zwrot $z$ inwestycji poniżej poziomu planowanego.

Finansowanie inwestycji w zmiennym otoczeniu decyzyjnym wymaga od zarządzających gotowości do zmian realizacji scenariusza przyjętego w planach, spowodowanych zmianami uwarunkowań procesu inwestycyjnego. Konsekwencją zmian mogą być odchylenia od planowanej stopy zwrotu. Jak oszacować ryzyko finansowe realizacji inwestycji?

Wybór instrumentu pomiaru nie może być przypadkowy. Należy pamiętać, że efektywność inwestycji - stopa zwrotu - jest zmienną losowa. Oznacza to, że stopa zwrotu $s^{(p)}$ jest zmienna, która może przyjąć wartości z pewnego przedziału zmienności $[a, b] \subset R$. Wybór skutecznego i nieskomplikowanego instrumentu pomiaru ryzyka o wiarygodnej zawartości informacyjnej miary ma istotne znaczenie. Inwestor oczekuje pełnej informacji o możliwych zagrożeniach procesu inwestycyjnego, łącznie z oszacowaniem ryzyka stopy zwrotu, nim podejmie decyzje o finansowaniu inwestycji.

Naturalną miarą ryzyka relacji (7) jest prawdopodobieństwo wystąpienia zdarzeń $B$. Taki pomiar jest możliwy pod warunkiem przeprowadzenia eksperymentu Monte Carlo, w wyniku którego zostaną wygenerowane ciagi losowe wartości stopy zwrotu.

Wattpliwości inwestora może osłabić bądź wzmocnić analiza oczekiwanej stopy zwrotu z inwestycji alternatywnych. Efektywność inwestycji alternatywnych wyznacza oczekiwana stopa zwrotu $s^{(i a)}$ portfela możliwych inwestycji o określonych stopach zwrotu - lokaty bankowe, bony skarbowe, obligacje Skarbu Państwa, pożyczki zabezpieczone papierami o wysokiej płynności czy zakup papierów dłużnych o krótkim terminie zwrotu zabezpieczonych majątkiem produktywnym o płynnej i natychmiastowej zbywalności.

Algorytm oceny ryzyka finansowania inwestycji przedstawiono poniżej.

1. Przyjęcie wartości planowanej stopy zwrotu $s^{(p)}$.

2. Oszacowanie przedziału wartości planowanej stopy zwrotu $[a, b]$. 
3. Określenie minimalnej oczekiwanej stopy zwrotu $s^{(i a)} \mathrm{z}$ inwestycji alternatywnych.

4. Wygenerowanie metodą Monte Carlo ciagu $\left\{s_{i}\right\}$ - stóp zwrotu przyjmujących wartości z przedziału $[a, b]$.

5. Oszacowanie ryzyka finansowego inwestycji zapewniającego stopę zwrotu na poziomie nie niższym niż planowany $s^{(p)}$

6. Oszacowanie ryzyka finansowego inwestycji zapewniającego oczekiwaną stope zwrotu z przedziału $\left[s^{(i a)}, s^{(p)}\right]$.

7. Oszacowanie ryzyka finansowego inwestycji w przypadku, gdy stopa zwrotu przyjmuje wartość na poziomie niższym niż oczekiwana stopa zwrotu inwestycji alternatywnych $s^{(i a)}$.

Redukcja niepewności związanej z wartością stopy zwrotu jest równoważna z oszacowaniem poziomu ryzyka finansowania inwestycji. Definicja ryzyka określa ten stan jednoznacznie, jako nieuzyskanie planowanego poziomu stopy zwrotu z inwestycji. Sporządzone plany inwestycyjne ujmują rozwiązania alternatywne z niższym poziomem stopy zwrotu, oceniane jako obciążone „mniejszym ryzykiem”. Uwzględnienie w analizie ryzyka finansowania inwestycji alternatywnych obok inwestycji planowanej - głównej definiuje dwa poniższe obszary ryzyka.

I Scenariusze realizacji inwestycji $s_{i}$ nie gwarantują stóp zwrotu na poziomie planowanej stopy zwrotu: $s_{i}<s^{(p)}$.

II Scenariusze realizacji $s_{i}$ inwestycji nie gwarantują stóp zwrotu na poziomie stopy zwrotu z inwestycji alternatywnych $s_{i}<s^{(i a)}$.

gdzie: $s_{i}$-wygenerowane w przedziale [a, b], metodą Monte Carlo wartości stóp zwrotu.

Przykład. Zakład Ubezpieczeń zamierza zakupić akcje dużego banku z zasobów własnych kapitału, eksperyment przeprowadzono przyjmując poniższe założenia.

1. Wartość planowanej stopy zwrotu na poziomie $s^{(p)}=6,4 \%$.

2. Wartość oczekiwana stopy zwrotu $z$ inwestycji alternatywnych $s^{(i a)}=3,5 \%$.

3. Analizowany przedział wartości stopy zwrotu $[a, b]=[0 \%, 8 \%]$.

4. Rozkład stóp zwrotu zgodny z rozkładem normalnym $(\mu=4, \sigma=3,29)^{8}$.

5. Wygenerowano 10000 wartości z przedziału $[0 \%, 8 \%]$.

$\mathrm{Na}$ podstawie przyjętych założeń oszacowano ryzyko finansowe inwestycji, mierzone prawdopodobieństwem stopy zwrotu $s$.

I Ryzyko osiagnięcia stopy zwrotu na poziomie nie niższym niż 6,4\%, mierzone prawdopodobieństwem wystąpienia takiego zdarzenia, oszacowano na poziomie 0,85 .

II Ryzyko nieosiąnięcia stopy zwrotu w granicach 3,5\%-6,4\% \%, mierzone prawdopodobieństwem wystąpienia takiego zdarzenia, oszacowano na poziomie 0,58 .

\footnotetext{
8 Jest to odchylenie standardowe w 90\%-owym przedziale ufności $\sigma=3,29$.
} 
III Ryzyko nieosiagnięcia stopy zwrotu na poziomie 3,5\% z inwestycji alternatywnych, mierzone prawdopodobieństwem wystąienia takiego zdarzenia, oszacowano na poziomie 0,52 .

Wyniki empiryczne nie są zaskoczeniem, gdyż potwierdzają wnioski z analizy teoretycznej. Teoria i empiria badanego przypadku są zgodne, natomiast poziom ryzyka wzrasta wraz ze wzrostem oczekiwań co do poziomu stóp zwrotu.

\section{Podsumowanie}

Wynik decyzji inwestycyjnych obciąża niepewność łącząca się z efektywnością poniesionych nakładów finansowych, a także okres ich zwrotu. Wydłużanie okresu zwrotu obniża efektywności inwestycji. Teza ta wynika wprost z definicji miary efektywności stopy zwrotu. Jednocześnie wydłużony okres zwrotu nakładów to okres pozostawania w środowisku większych bądź mniejszych turbulencji otoczenia inwestycyjnego. Niezależnie od skali zakłóceń, odchylenia uwarunkowań decyzyjnych od przyjętych w planach inwestycyjnych są źródłem ryzyka finansowego inwestycji, mierzonego prawdopodobieństwem zrealizowanej stopy zwrotu. Skutki podjętego ryzyka mogą być przyczyną utraty płynności finansowej, co stawia inwestora w trudnej sytuacji finansowej, który traci zdolność do obsługi zobowiązań wobec instytucji finansowych użyczających środki stanowiące finansowanie zewnętrzne. Równocześnie inwestor, nie uzyskując zwrotu z środków własnych, ponosi starty.

Identyfikacja prawdopodobnych scenariuszy realizacji stopy zwrotu, oszacowanej przy użyciu metody Monte Carlo, jest przybliżeniem modelu rozkładu, niedającego się obserwować rozkładu rzeczywistego zarówno przeszłych, jak i przyszłych stóp zwrotu, a wynik jest rezultatem zbliżonym do konstrukcji modelu próbki rozkładu stóp [Kritzman, 2011]. Mimo tej wady, rozwiązanie umożliwia oszacowanie prawdopodobieństwa ryzyka scenariuszy stóp zwrotu finansowania inwestycji. Informacja ta ma pierwszoplanowe znaczenie w systemie monitoringu zmian tych uwarunkowań otoczenia, które istotnie wpływają na poziom stopy zwrotu. Ta cecha systemu monitoringu stanowi fundament systemu instrumentów zabezpieczeń przed skutkami ryzyka finansowania inwestycji.

Eksperyment Monte Carlo rozwiązał wiele znaczących problemów natury praktycznej. Obliczenie prędkości cząsteczek metodą Monte Carlo przez generowanie prędkości cząsteczek trytu w trakcie wybuchu bomby wodorowej, dokonane przez E. Tellera i S. Ulama w 1952 roku, uznawane jest za moment opracowania tej metody. Jej zaleta było zastąpienie czasochłonnych rozwiązań analitycznych. Dzięki rosnącej mocy komputerów, metoda uwolniła badaczy od skomplikowanych teorii i wzorów, a to pozwoliło im na skupieniu się na praktycznej stronie problemu. Obok niepodważalnych zalet, metoda ma zauważalne wady, a mianowicie: ograniczenie eksperymentów do skończonej liczby prób, otrzymane wyniki są przybliżeniem, a ich jakość zależy od użytego generatora liczb pseudolosowych.

Rozwiąaniem zbliżonym do prezentowanej metody Monte Carlo jest metoda Bootstrap. Zakłada ona, że rozkład teoretyczny jest aproksymantą rzeczywistego rozk- 
ładu stóp zwrotu. Jednakże zbiór ten ma ważną własność, bowiem może stanowić fundament procesu generowania scenariuszy, które będą kreowane na podstawie danych historycznych i moga obejmować statystyki o właściwościach historycznych [Kritzman, 2011], co umożliwia doprecyzowanie wyniku otrzymanego metodą Monte Carlo.

\section{Literatura}

Coates J., Davis E. W., Emmanuel C., Longden S., Stacey R. J., 1993, Corporate Performance Evaluation in Multinationals, Chartered Institute of Management Accountants, London.

Gołębiowski T., 2001, Zarzadzanie strategične. Planowanie i kontrola, Wydawnictwo Difin, Warszawa

Halton J., 1970, A Retrospective and Prospective Survey of the Monte Carlo Method, "SIAM Review", vol. 12, no. 1

Hay D.A., Morris D.J., 1987, Industrial Economics: Theory and Evidence, Oxford University Press, Oxford.

Hubbard D. W., 2011, Pomiar Uniwersalny. Odkerywanie w biznesie wartości niematerialnych, MT Biznes Sp. z o.o., Warszawa.

Jajuga K., 2009, Wprowadzenie do inwestyci finansowych. Deposyty i instrumenty rynku pienieżnego, Komisja Nadzoru Finansowego, Warszawa.

Kritzman M. P., 2011, Paradoksy inwestowania. Metody zwiekszajace ayskownośc i bezpieczeńnstwo portfela, CeDeWu Sp. z o.o., Warszawa.

Leclerc G., L., 2010, Essays on Moral Arithmetic, LSF Research Working Paper Series, no. 10-16, Luxemburg.

Metropolis N., 1987, The Beginning of the Monte Carlo Method, Los Alamos Science, Special Issue, no. 15.

Metropolis N., Ulam S., 1949, The Monte Carlo Method, "Journal of the American Statistical Association", vol. 44, no. 247.

Ocena efektywności inwestycji, 2003, P. Karpuś (red.), CeDeWu Sp. z o.o., Warszawa.

Ostrowska E., 1999, Ryzyko inwestycyjne. Identyfikacja i metody oceny, Wydawnictwo Uniwersytetu Gdańskiego, Gdańsk.

Rappaport A., 1986, Creating Shareholder V alue, Free Press, New York.

Rogowski W., 2013, Racbunek efektywności inwestycji. Wyžwania teorii i potrzeby praktyki, Wolters Kluwer, Kraków.

Sobol L., 1975, The Monte Carlo Method, Mir Publisher, Moskwa.

Thomson A.A., Strickland A.J., 1998, Strategic Management, ed. 10, R. D. Irwin (ed.), McGraw-Hill, Boston.

Tocher K.D., 1969, The art of simulation, English Universities Press, London.

Zieliński R., 1970, Metody Monte Carlo, Wydawnictwo Naukowo-Techniczne, Warszawa.

Zieliński R., 1979, Generatory liç̧b losonych, Wydawnictwo Naukowo-Techniczne, Warszawa. 


\section{Załącznik 1.}

\begin{tabular}{|c|c|c|}
\hline \multicolumn{3}{|c|}{ Oczekiwana stopa zwrotu $\geq 6,4 \%$} \\
\hline $\begin{array}{l}\text { Numer scena- } \\
\text { riusza }\end{array}$ & $\begin{array}{l}\text { Wygenerowane } \\
\text { stopy zwrotu }\end{array}$ & $\begin{array}{c}\text { Wartość logiczna relacji (wsz } \geq 6,4 \% \text { ) } \\
\text { wsz - wygenerowana stopa zwrotu }\end{array}$ \\
\hline 1 & 2,65 & - \\
\hline 2 & 1,37 & - \\
\hline 3 & 6,44 & 1 \\
\hline 4 & 3,75 & - \\
\hline & & 15 \\
\hline 9999 & 1,02 & - \\
\hline 10000 & 3,59 & - \\
\hline \multicolumn{2}{|c|}{$p(B)=0,85$} & $\Sigma(W$ artość logiczna [wsq $\geq 6,4 \%] / 10000)$ \\
\hline
\end{tabular}

\begin{tabular}{|c|c|c|}
\hline \multicolumn{3}{|c|}{ Oczekiwana stopa zwrotu < 3,5\% } \\
\hline $\begin{array}{c}\text { Numer scena- } \\
\text { riusza }\end{array}$ & $\begin{array}{c}\text { Wygenerowane } \\
\text { stopy zwrotu }\end{array}$ & $\begin{array}{c}\text { Wartość logiczna relacji (wsz <3,5\%) } \\
\text { wsz - wygenerowana stopa zwrotu }\end{array}$ \\
\hline 1 & 4,18 & 1 \\
\hline 2 & 3,78 & 1 \\
\hline 3 & 5,44 & 1 \\
\hline 4 & 1,50 & 1 \\
\hline \hline & 6,04 & 1 \\
\hline 9999 & 4,09 & $\sum$ (Wartoś́ logiczna[wsz <3,5\%]/10 000) \\
\hline 10000 & $p(B)=0,52$ &
\end{tabular}

\begin{tabular}{|c|c|c|}
\hline \multicolumn{3}{|c|}{ Oczekiwana stopa zwrotu w granicach 3,5\% - 6,4\% } \\
\hline $\begin{array}{l}\text { Numer scena- } \\
\text { riusza }\end{array}$ & $\begin{array}{l}\text { Wygenerowane } \\
\text { stopy zwrotu }\end{array}$ & $\begin{array}{c}\text { Wartość logiczna relacji }(3,5 \%<\text { wsz }<6,4 \%) \\
\text { wsz - wygenerowana stopa zwrotu }\end{array}$ \\
\hline 1 & 2,65 & - \\
\hline 2 & 1,37 & - \\
\hline 3 & 6,44 & - \\
\hline 4 & 3,75 & 1 \\
\hline 7 & & 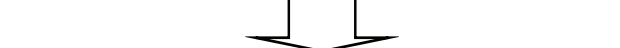 \\
\hline 9999 & 1,02 & - \\
\hline 10000 & 3,59 & 1 \\
\hline \multicolumn{2}{|c|}{$p(B)=0,58$} & $\Sigma($ Wartosí logična $[3,5 \% \leq$ wsz $<6,4 \%] / 10000)$ \\
\hline
\end{tabular}


Definicja operatu losowania: rozkład.normalny.odw(los ()$; \mu ;(a-b) / \sigma)$, gdzie przedział $[\mathrm{a}, \mathrm{b}]=[0,8], \mu$ - wartość przeciętna przedziału losowania (generowania), $\sigma$ - odchylenie standardowe. Przyjęto założenie o zgodności zmiennej losowej wsz z rozkładem normalnym, a jej generowanie przeprowadzono metodą odwracania dystrybuanty. 